\title{
Targeted Cleavage of HIV Rev Response Element RNA by MetalloPeptide Complexes
}

Yan Jin and J. A. Cowan*

Evans Laboratory of Chemistry, Ohio State University, 100 West $18^{\text {th }}$ Avenue, Columbus, Ohio 43210

\section{SUPPORTING MATERIAL}

\section{MATERIALS \& METHODS}

1.1 General materials. The peptides used in this study were purchased from Genemed Synthesis Inc (South San Francisco, CA). RRE RNA, with or without 5' fluorescein labeling, was purchased from Dharmacon RNA Technologies (Lafayette, CO). All materials were prepared under RNase free conditions as previously described ${ }^{1}$ or purchased in the highest commercially available grades. Unless stated, all other reagents used in this research were obtained from Sigma chemical Co.

1.2 Synthesis and characterization. A solution of $2.2 \mathrm{mM}$ peptide in $50 \mathrm{mM}$ Hepes buffer $(\mathrm{pH}$ $=7.4$ ) was mixed with $2 \mathrm{mM} \mathrm{CuCl}_{2}$ in $50 \mathrm{mM}$ Hepes buffer solution in $1: 1 \mathrm{v}: \mathrm{v}$ ratio. This yielded a 1.1:1 peptide to copper ratio, and so there was no free $\mathrm{Cu}^{2+}$ (aq) ion in the cleavage reaction mixture. The resulting solution was mixed at room temperature for $\sim 30 \mathrm{~min}$, resulting in a stable light reddish-purple solution that displayed a UV-vis spectrum typical of Cu-ATCUN complexes. ${ }^{2}$ Samples were maintained at $4{ }^{\circ} \mathrm{C}$ and concentrations and stabilities of the $\mathrm{Cu}-$ peptide complexes were routinely checked prior to use.

1.3 Fluorescence spectroscopy. A $300 \mu \mathrm{L}$ volume of a $6 \mathrm{nM}$ solution of 5'-fluorescein labeled RRE RNA (molecular concentration) was prepared in $20 \mathrm{mM}$ Hepes buffer, $100 \mathrm{mM} \mathrm{NaCl}, \mathrm{pH}=$ 7.4 , and the fluorescence response before and after addition of a $1 \mu \mathrm{l}$ aliquot of $5 \mu \mathrm{M}$ peptide or Cu-peptide complex was measured in a quartz cuvette at room temperature using a Perkin Elmer LS50B spectrofluorimeter, with excitation $(\mathrm{SW}=6 \mathrm{~nm})$ and emission $(\mathrm{SW}=6 \mathrm{~nm})$ wavelengths set at $490 \mathrm{~nm}$ and $515 \mathrm{~nm}$, respectively. Dissociation constants were obtained by fitting fluorescence quenching date to a one site binding equation $r=$ B.[pep] / $\left(K_{d}+\right.$ [pep] $)$ with binding function $r$ (where $r=\left(y_{t}-y_{0}\right) /\left(y_{\text {final- }} y_{\text {initial }}\right)$ ) versus [pep] is the concentration of metalfree or metal-bound peptide (Figure SM1). Each point was corrected for the dilution effect. Since our $\mathrm{Cu}-\mathrm{Rev} 1$ complex has very little absorbance $\left(\varepsilon_{515} \sim 30 \mathrm{M}^{-1} \mathrm{~cm}^{-1}\right)$, the inner filter effect ${ }^{3}$ is negligible in this assay.

1.4 RNA cleavage studies with gel electrophoresis. In general, RNA cleavage reactions were performed in $5 \mu \mathrm{l}$ total volumes with $10 \mu \mathrm{M}$ 5'-fluorescein labeled RRE RNA (molecular concentration), various concentrations of $\mathrm{Cu}$-peptide complexes, and with or without added ascorbate in $20 \mathrm{mM}$ Hepes buffer, $100 \mathrm{mM} \mathrm{NaCl}, \mathrm{pH}=7.4$ at $37^{\circ} \mathrm{C}$. Control reactions were carried out at the same time (Figures SM2 to SM4). The reactions were quenched with a loading buffer containing $8 \mathrm{M}$ Urea and $0.5 \mathrm{M}$ EDTA, but without dyes. ${ }^{1}$ The loading buffer 
with dyes was run in another lane. The reaction samples were loaded onto either $15 \%$ or $20 \%$ polyacrylamide/8M urea denaturing gels (from American Bioanalytical) and electrophoresed at $300 \mathrm{~V}$ for $5-8 \mathrm{~h}$. To avoid degradation or photobleaching of fluorescein, the reactions and gel eletrophoresis were performed in the dark. Each experiment was carried out at least in triplicate.

1.5 Mass spectrometric characterization of RNA cleavage products. RNA cleavage reactions were performed in $40 \mu \mathrm{l}$ total volumes with $100 \mu \mathrm{M}$ unlabeled RRE RNA, 1:1 concentration ratio of $\mathrm{Cu}$-peptide complex with, $1 \mathrm{mM}$ ascorbate in $20 \mathrm{mM}$ Hepes buffer, $100 \mathrm{mM} \mathrm{NaCl}, \mathrm{pH}=$ 7.4 at $37{ }^{\circ} \mathrm{C}$. Control reactions were carried out with RRE RNA and ascorbate. ESI/MS was used to get the mass of the cleavage products. Electrospray ionization (ESI) experiments were performed on a Micromass Q-Tof(tm) II (Micromass, Wythenshawe, UK) mass spectrometer equipped with an orthogonal nanospray source from New Objective, Inc. (Woburn, MA) operated in negative ion mode. Sodium Iodide was used for mass calibration for a calibration range of $\mathrm{m} / \mathrm{z} 500$ - 3000. Salt buffers from the RNA samples were removed using ZipTips (Millipore, Billerica, MA) following recommended manufacturer protocols. The elutants from the ZipTip were used directly and infused into the electrospray source at a rate of $2 \mathrm{ml}^{-\mathrm{min}^{-1}}$. Optimal ESI conditions were: capillary voltage $3000 \mathrm{~V}$, source temperature $110{ }^{\circ} \mathrm{C}$ and a cone voltage of $60 \mathrm{~V}$. Q1 was set to optimally pass ions from m/z $500-3000$ and all ions transmitted into the pusher region of the TOF analyzer were scanned over this $\mathrm{m} / \mathrm{z}$ range with a $1 \mathrm{~s}$ integration time. Data was acquired in continuum mode until acceptable averaged data was obtained (10 -15 minutes). ESI data was deconvoluted using MaxEnt I provided by Micromass (Figures SM5 to SM7) and the cleavage sites were assigned (Figure SM8, Scheme SM1, Table SM1). It is general practice to analyze the products of an RNA cleavage reaction by mass spectrometry where the reaction mixture contains at least 2 nmole of substrate, ${ }^{4-6}$ since it is technically difficult to extract the RNA products from a gel and then do the analysis. (see for example Meng, M.; Limbach, P. A. Int. J. Mass Spectrom. 2004, 234, 37-44.; Meng, M.; Limbach, P. A. Anal. Chem. 2005, 77, 1891-1895.; De Iuliis, G. N.; Lawrance, G. A.; Wilson, N. L. Inorg. React. Mech. 2002, 4, 169-186). 
Figures for Supplementary Material.

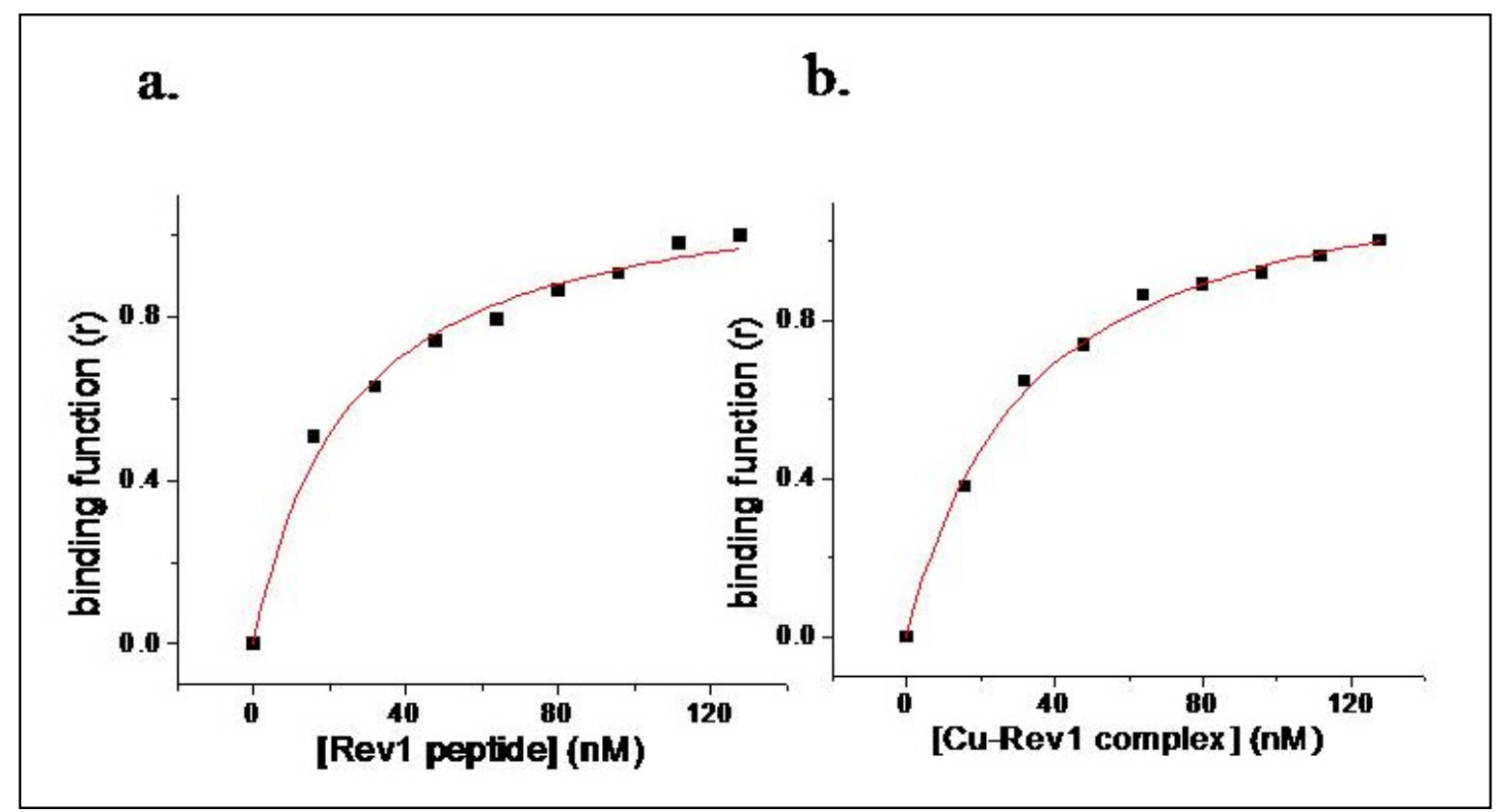

Figure SM1. Determination of $\mathrm{K}_{\mathrm{D}}$ 's for complex formation of RRE RNA with Rev1 and CuRev1. The $K_{D}$ for RRE binding to Rev1 is $\sim 30 \mathrm{nM}$ (a), while $K_{D}$ for RRE binding to Cu-Rev1 is $\sim 35 \mathrm{nM}$ (b). These numbers are consistent with the $\mathrm{K}_{\mathrm{D}}$ measured for RRE RNA and native Rev peptide lacking the ATCUN motif $(\sim 40 \mathrm{nM}){ }^{7}$ consistent with the absence of any significant influence of the N-terminal GGH sequence, or its copper complex, on binding to the RRE RNA 


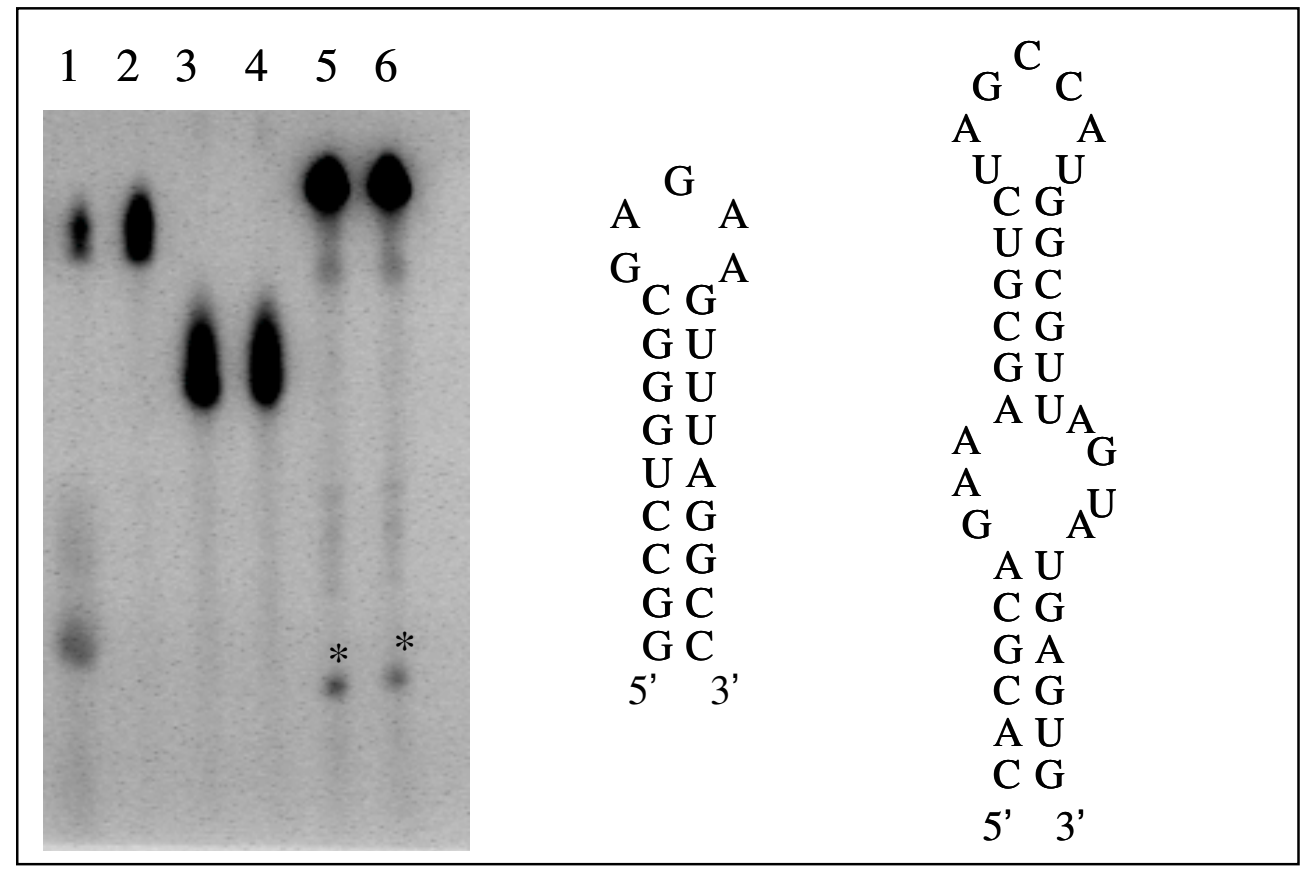

Figure SM2. (left) RNA cleavage of 5' FL labeled RRE, R23, and HCV IRES RNA by $\mathrm{Cu}^{2+}$ Rev1 peptide complex in the presence of $\mathrm{O}_{2}$ and ascorbate. Lanes: 1 . RRE $(10 \mu \mathrm{M})+\mathrm{Cu}^{2+}-\mathrm{Rev} 1$ peptide complex $(10 \mu \mathrm{M})+$ ascorbate $(100 \mu \mathrm{M}) ; 2$. RRE RNA $(10 \mu \mathrm{M})+$ ascorbate $(100 \mu \mathrm{M}) ; 3$. $\mathrm{R} 23(10 \mu \mathrm{M})+\mathrm{Cu}^{2+}-\mathrm{Rev1}$ peptide complex $(10 \mu \mathrm{M})+$ ascorbate $(100 \mu \mathrm{M}) ; 4$. R23 RNA (10 $\mu \mathrm{M})+$ ascorbate $(100 \mu \mathrm{M}) ; 5$. HCV IRES RNA $(10 \mu \mathrm{M})+\mathrm{Cu}^{2+}-\mathrm{Rev} 1$ peptide complex $(10 \mu \mathrm{M})$ + ascorbate $(100 \mu \mathrm{M}) ; 6$. HCV IRES RNA $(10 \mu \mathrm{M})+$ ascorbate $(100 \mu \mathrm{M})$; Reactions were incubated in $20 \mathrm{mM}$ Hepes buffer, $100 \mathrm{mM} \mathrm{NaCl}, \mathrm{pH}=7.4$, for 3 hours at $37^{\circ} \mathrm{C}$. Reaction products were separated by $15 \%$ denaturing PAGE. Some impurities (*) in the HCV IRES sample are noted. (middle) a schematic illustration of the stem loop structure adopted by R23, ${ }^{8}$ and (right) a schematic illustration of the secondary structure of the internal ribosome entry site (IRES) RNA of Hepatitis C Virus (HCV). ${ }^{9}$ 


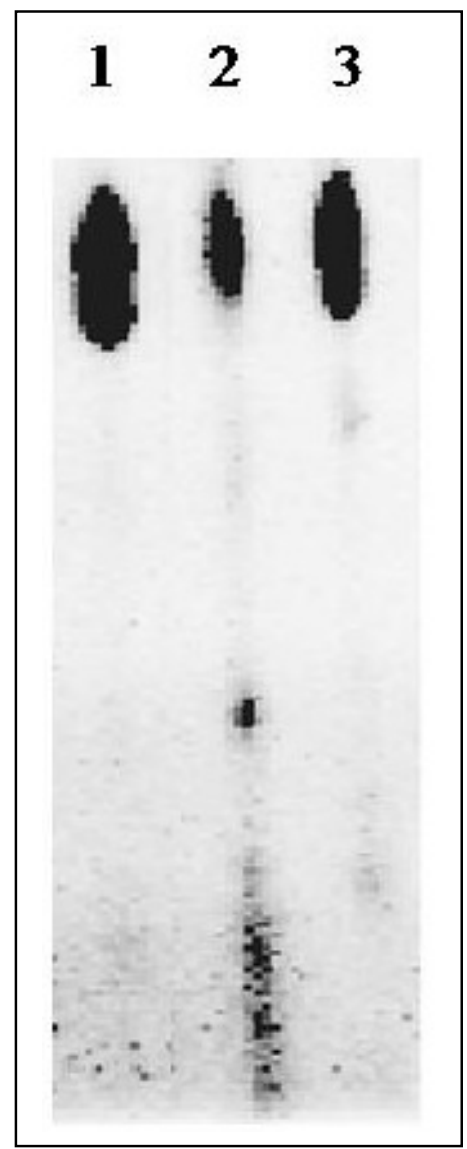

Figure SM3. RNA cleavage of 5' FL labeled RRE RNA by $\mathrm{Cu}^{2+}$ Rev1 peptide complex or $\mathrm{Cu}^{2+}-\mathrm{KGHK}$ in the presence of $\mathrm{O}_{2}$ and ascorbate. Lanes: 1. RRE RNA $(10 \mu \mathrm{M})+$ ascorbate $(100 \mu \mathrm{M}) ; 2$, $\operatorname{RRE}(10 \mu \mathrm{M})+\mathrm{Cu}^{2+}-\mathrm{Rev} 1$ peptide complex $(10 \mu \mathrm{M})+$ ascorbate $(100 \mu \mathrm{M}) ; 3$. RRE $(10 \mu \mathrm{M})+\mathrm{Cu}^{2+}-\mathrm{KGHK}$ complex $(10 \mu \mathrm{M})+$ ascorbate $(100 \mu \mathrm{M})$. Reactions were incubated in $20 \mathrm{mM}$ Hepes buffer, $100 \mathrm{mM} \mathrm{NaCl}, \mathrm{pH}=7.4$, for 3 hours at $37{ }^{\circ} \mathrm{C}$. Reaction products were separated by $20 \%$ denaturing PAGE. 


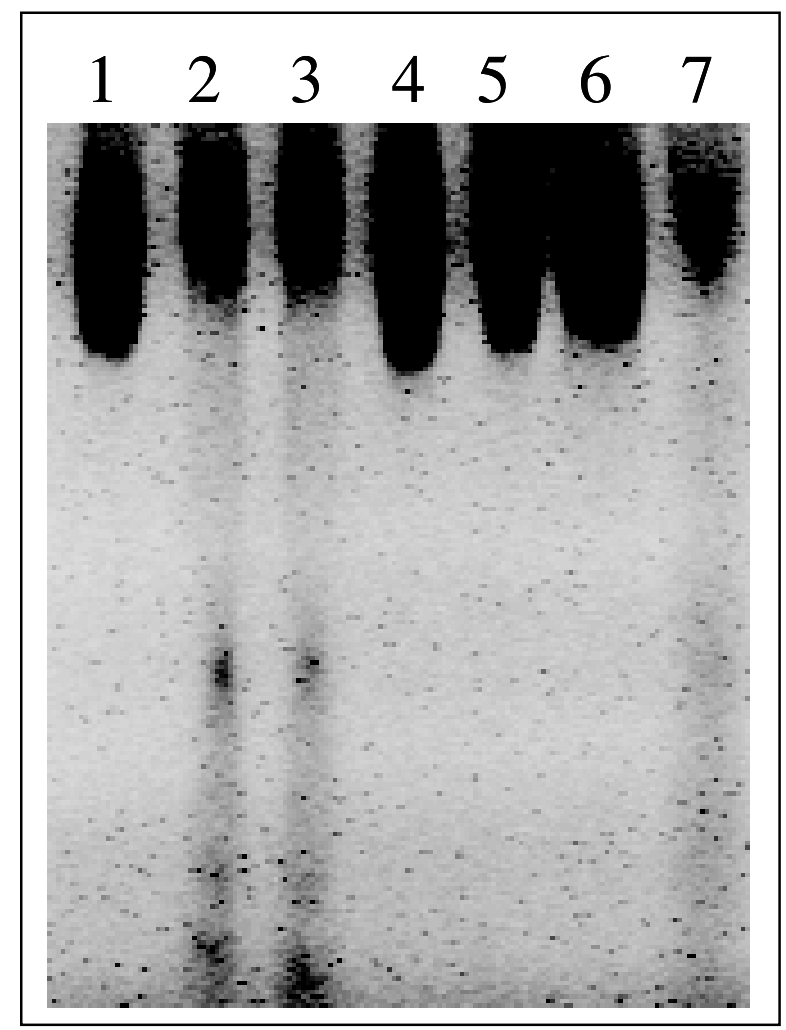

Figure SM4. RNA cleavage of 5' FL labeled RRE RNA by $\mathrm{Cu}^{2+}$ - Rev1 peptide complex in the presence of $\mathrm{O}_{2}$ and ascorbate. Lanes: 1 . RRE RNA $(10 \mu \mathrm{M}) ; 2$, 3 RRE $(10 \mu \mathrm{M})+\mathrm{Cu}^{2+}$ Rev1 peptide complex $(10 \mu \mathrm{M})+$ ascorbate $(100 \mu \mathrm{M})$; 4. RRE RNA $(10 \mu \mathrm{M})+$ ascorbate $(100 \mu \mathrm{M})$; 5. RRE RNA $(10 \mu \mathrm{M})+\operatorname{Rev} 1$ peptide $(10 \mu \mathrm{M})$; 6 . RRE RNA $(10 \mu \mathrm{M})+\mathrm{Cu}^{2+}$ (aq) $(10 \mu \mathrm{M}) 7$. RRE $(10 \mu \mathrm{M})+\mathrm{Cu}^{2+}$ (aq) $(10$ $\mu \mathrm{M})+$ ascorbate $(100 \mu \mathrm{M})$. Reactions were incubated in $20 \mathrm{mM}$ Hepes buffer, $100 \mathrm{mM}$ $\mathrm{NaCl}, \mathrm{pH}=7.4$, for 3 hours at $37^{\circ} \mathrm{C}$. Reaction products were separated by $20 \%$ denaturing PAGE 


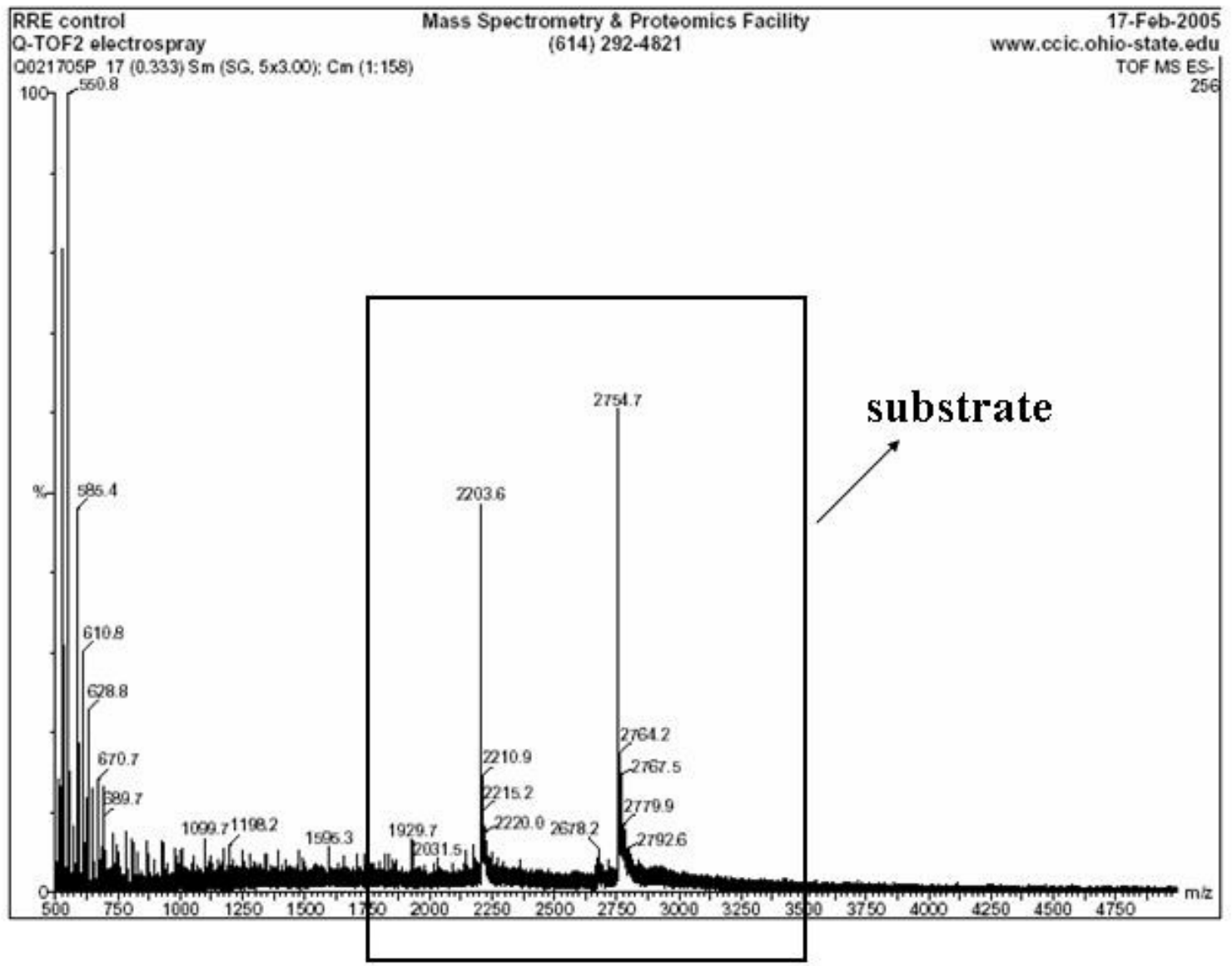

Figure SM5. Control reaction for RRE RNA cleavage analyzed by mass spectrometry. The control reaction was performed under similar solution conditions, but without the $\mathrm{Cu}$-peptide complex. 


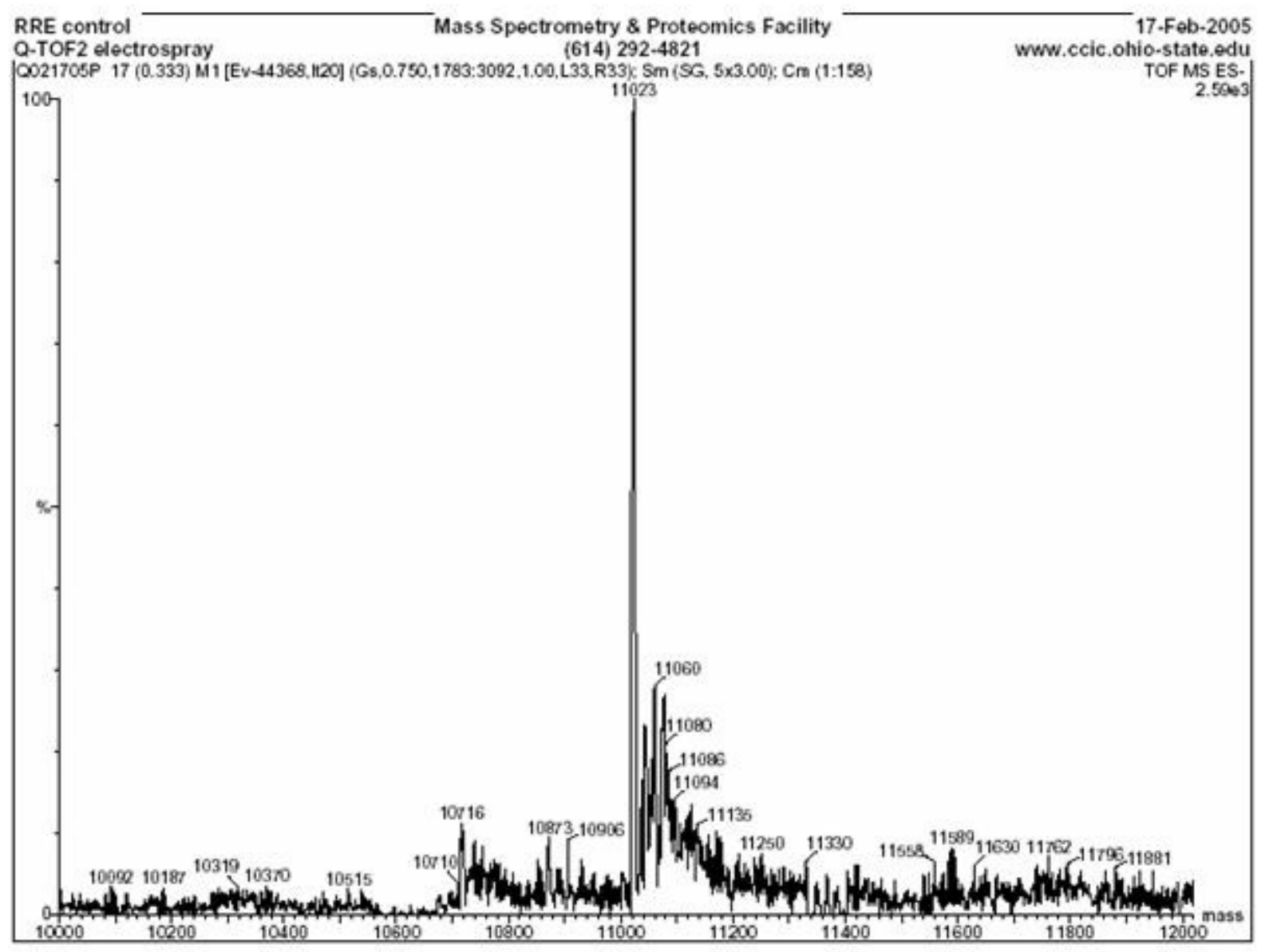

Figure SM6. Control reaction for RRE RNA cleavage showing the accurate mass for substrate RRE RNA following deconvolution. 


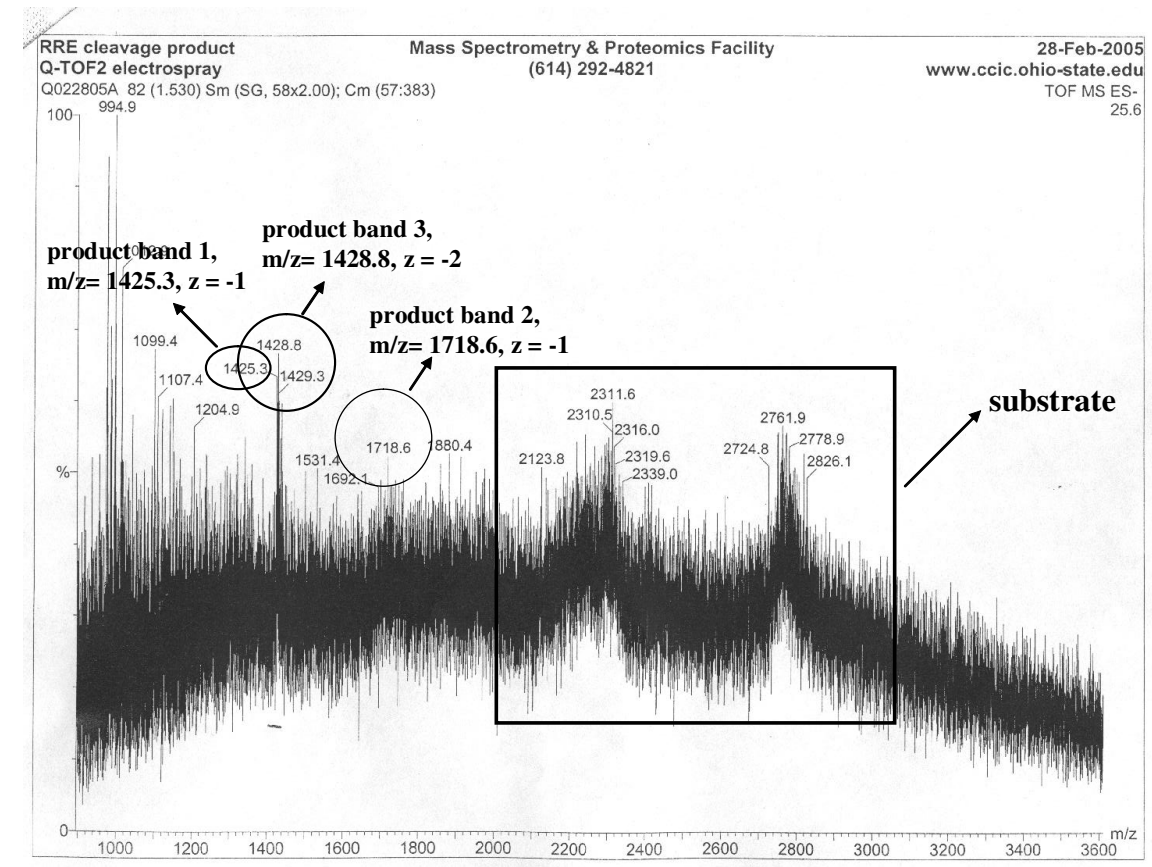

Figure SM7. Mass spectrometric analysis of the product mixture following the RRE cleavage reaction performed as described in Materials and Methods.

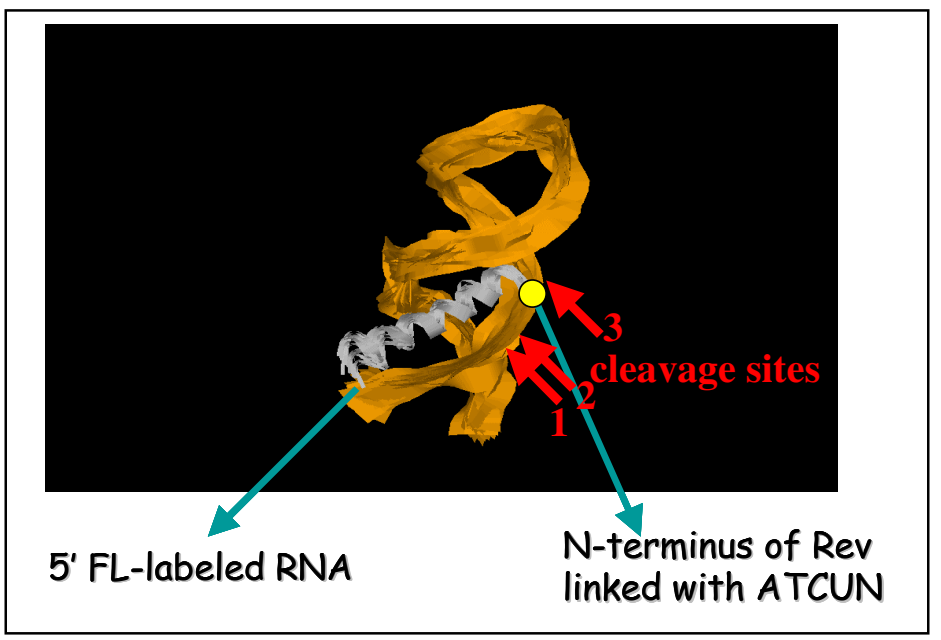

Figure SM8. NMR characterized tertiary structures of RRE RNA and Rev peptide, ${ }^{10}$ showing the binding pocket and cleavage sites determined from mass spectrometric analysis. 


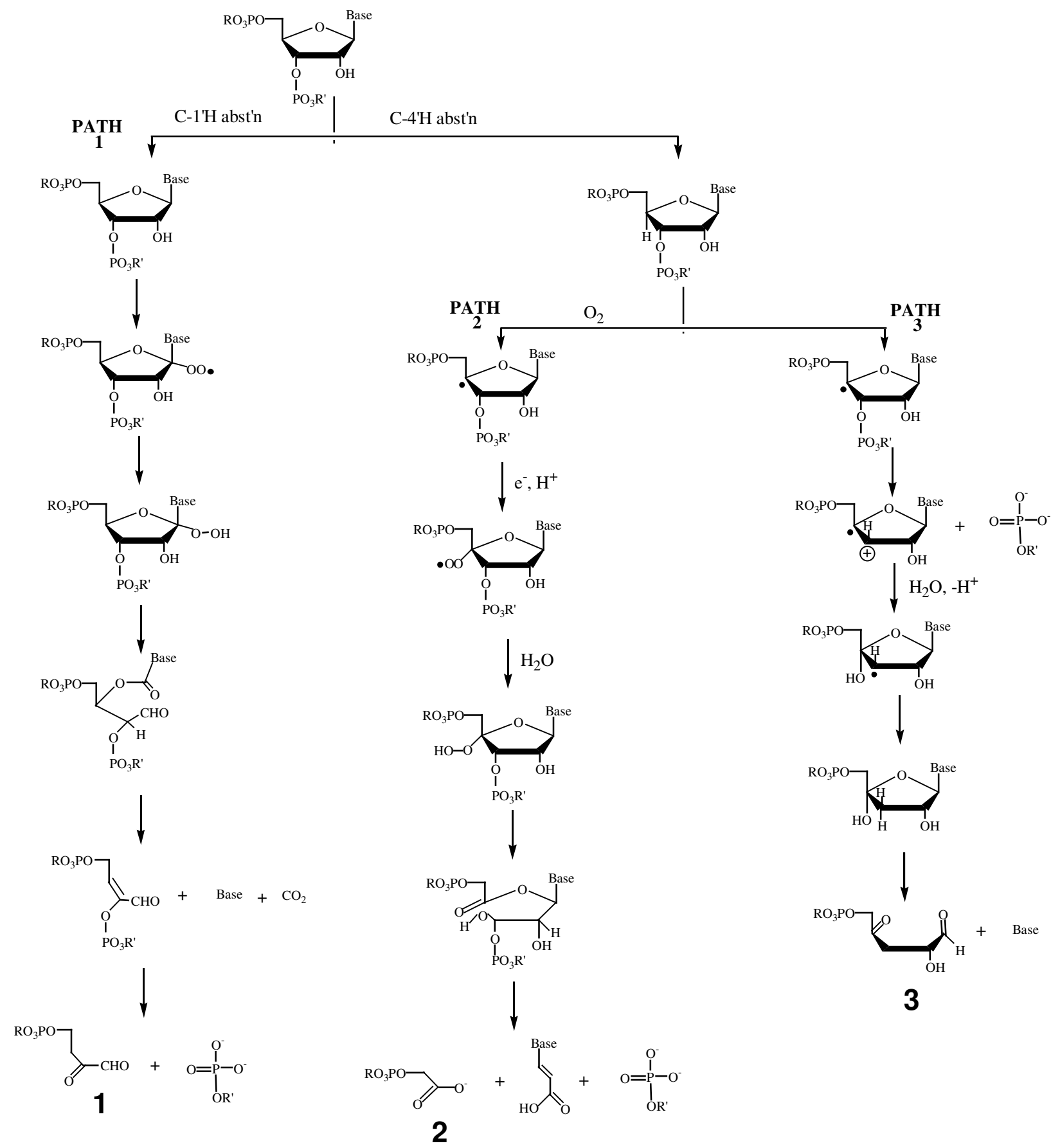

Scheme SM1. Proposed mechanism of RRE RNA cleavage by the $\mathrm{Cu}^{2+}-\mathrm{Rev1}$ complex with ascorbate under aerobic conditions (paths 1, 2, 3 leading to products $\mathbf{1}, \mathbf{2}$, and $\mathbf{3}$, as defined in Table SM1). 
Table SM1. ESI-MS analysis of the cleavage products following treatment of RRE by the $\mathrm{Cu}^{2+}$ Rev1 complex with ascorbate. ${ }^{a}$

\begin{tabular}{|c|l|l|l|l|}
\hline $\begin{array}{l}\text { product } \\
\text { band on gel }\end{array}$ & sequence assignment & found $\mathrm{m} / \mathrm{z}$ & $\begin{array}{l}\text { predicted } \mathrm{m} / \mathrm{z} \\
\text { for hydrolytic } \\
\text { cleavage }\end{array}$ & $\begin{array}{l}\text { predicted } \mathrm{m} / \mathrm{z} \\
\text { for oxidative } \\
\text { cleavage }\end{array}$ \\
\hline $\mathbf{1}$ & 5'-GGUC-Pi-X $^{b}-3^{\prime}$ & $1425.3^{c}$ & $1318.7^{c}$ & $1425.7^{c, e}$ \\
\hline $\mathbf{2}$ & 5'-GGUCU- Pi-X $^{b}-3^{\prime}$ & $1718.6^{c}$ & $1624.9^{c}$ & $1720.9^{c, f}$ \\
\hline $\mathbf{3}$ & $5^{\prime}$-GGUCUGGG- Pi-X ${ }^{b}-3^{\prime}$ & $1428.8^{d}$ & $1329.8^{d}$ & $1428.4^{d, g}$ \\
\hline
\end{tabular}

${ }^{a}$ Predicted mass values are based on atomic weight as $(\mathrm{M}+\mathrm{H})^{-}$unless specially stated. Cleavage products are determined from Fig SM7. ${ }^{b} \mathrm{X}$ stands for the partial ribose left after cleavage. In the case of hydrolytic cleavage, mass of $\mathrm{X}$ is zero. ${ }^{c} \mathrm{z}$ is $-1 .{ }^{d} \mathrm{Z}$ is $-2 .{ }^{e}$ cleavage product through C-1'H abstraction with $\mathrm{X}$ : $\mathrm{CH}_{2} \mathrm{CH}_{2} \mathrm{COCHO}$ (through path 1 in Scheme SM1). ${ }^{11}$ Mass of (M + $\mathrm{Na})^{-}$was calculated. ${ }^{f}$ cleavage product through $\mathrm{C}-4^{\prime} \mathrm{H}$ abstraction $\left(\mathrm{O}_{2}\right)$ with $\mathrm{X}: \mathrm{CH}_{2} \mathrm{COO}^{-}$ (through path 2 in Scheme SM1). ${ }^{12,13}$ Mass of $(\mathrm{M}+\mathrm{K})^{-}$was calculated. ${ }^{g}$ cleavage product through C-4' $\mathrm{H}$ abstraction $\left(\mathrm{H}_{2} \mathrm{O}\right)$ with $\mathrm{X}: \mathrm{CH}_{2} \mathrm{COCH}_{2} \mathrm{CH}(\mathrm{OH}) \mathrm{CHO}$ (through path 3 in Scheme SM1). ${ }^{14}$ Mass of $(\mathrm{M}+2 \mathrm{Na}+\mathrm{K})^{2-}$ was calculated.

\section{$\underline{\text { SM References }}$}

(1) Sambrook, J.; Fritsch, E. F.; Maniatis, T. Molecular Cloning; Cold Spring Harbor Laboratory Press: New York, 1989.

(2) Lau, S.-J.; Kruck, T. P. A.; Sarkar, B. J. Biol. Chem. 1974, 249, 5878-5884.

(3) Encinas, M. V.; Rojas, M. C.; Goldie, H.; Cardemil, E. Biochimica et Biophysica Acta. 1993, 1162, 195-202.

(4) De Iuliis, G. N.; Lawrance, G. A.; Wilson, N. L. Inorg. React. Mech. 2002, 4, 169-186.

(5) Meng, M.; Limbach, P. A. Int. J. Mass Spectrom. 2004, 234, 37-44.

(6) Meng, M.; Limbach, P. A. Anal. Chem. 2005, 77, 1891-1895.

(7) Harada, K.; Martin, S. S.; Tan, R.; Frankel, A. D. Proc. Natl. Acad. Sci. USA 1997, 94, 11887-11892.

(8) Sreedhara, A.; Patwardhan, A.; Cowan, J. A. Chem. Commun. 1999, 1147-1148.

(9) Tang, S.; Collier, A. J.; Elliott, R. M. J. Virol. 1999, 73, 2359-2364.

(10) Battiste, J. L.; Mao, H.; Rao, N. S.; Tan, R.; Muhandiram, D. R.; Kay, L. E.; Frankel, A. D.; Williamson, J. R. Science 1996, 273, 1547-1551.

(11) Zeng, X.; Xi, Z.; Kappen, L. S.; Tan, W.; Goldberg, I. H. Biochemistry 1995, 34.

(12) Hecht, S. M. Acc. Chem. Res. 1986, 19, 383-391.

(13) Pogozelski, W. K.; Tullius, T. D. Chem. Rev. 1998, 98, 1089-1107.

(14) Sonntag, C. V. The Chemical Basis of Radiation Biology; Taylor \& Francis: London, 1987. 